\title{
PENGUATAN PRINSIP SYARIAH PADA PRODUK BANK SYARIAH
}

\author{
Mohamad Ainun Najib \\ Dosen Ekonomi Islam Fakultas Ekonomi dan Bisnis \\ Universitas Sultan Ageng Tirtayasa Serang Banten \\ najib.marza@gmail.com
}

\begin{abstract}
Abstrak
$\mathrm{B}$ ank Syariah Mengalami pertumbuhan yang signifikan di Indonesia dan mendapat sambutan yang luas dari masyarakat. Sudah menjadi keniscayaan, bank syariah yang bersumber dari syariah Allah yang tertuang di dalam al-Qur'an dan as-Sunnah harus memastikan setiap produknya sesuai dengan syariah. Asas kepatuhan syariah bisa terlaksana didasarkan kepada pemahaman prinsip syariah yang detail dan komprehensif. Di antara prinsip Fundamental Bank Syariah adalah tidak melakukan transaksi riba, gharar, maisir, dan produk yang haram. Bank Syariah dalam produk penghimpunan dana simpanan giro dan tabungan menggunakan prinsip wadi'ah dan deposito menggunakan akad mudharabah.
\end{abstract}

Kata Kunci: Prinsip-Prinsip Syariah, Bank Syariah, Produk Penghimpunan

\begin{abstract}
$I$ slamic Banking is Experiencing significant growth in Indonesia and gaining the widespread acceptance of the public. It has become a necessity, Islamic banks which derived from the law of God contained in the Qur'an and Sunnah shall ensure any of their products comply to the sharia law. The compliance to sharia principles could be implemented based on the comprehensive and detail understanding on sharia principles. Among the fundamental principles of Islamic Banking are prohibition of riba, gharar and maysir (gambling) and also producing haram product. Funding products in Islamic Bank are using wadiah contract for demand deposits and using mudharabah contract for investment/ time deposits.
\end{abstract}

Keywords: Sharia Principles, Islamic Banks, Funding Products

\section{Pendahuluan}

\section{Latar Belakang}

Indonesia sebagai negara yang penduduknya mayoritas beragama Islam, termasuk negara yang pertumbuhan lembaga keuangan syariahnya cukup pesat.Secara Internasional Indonesia dipandang sebagai kekuatan dan memiliki potensi besar keuangan syariah global, menurut Islamic Finance Development Report 2014 Indonesia masuk Top 10 Islamic Finance Asset (\$ Million) menempati urutan ke 9 dengan asset 35,626. Peringkat 1 ditempati Malaysia dengan total asset $423,285 .^{20}$

Indonesia juga telah memperoleh pengakuan internasional di antaranya ; bersama dengan UAE, Arab Saudi, Malaysia dan Bahrain, Indonesia saat ini sudah dianggap berada dalam posisi to offer lessons kepada negara lain di dunia untuk pengembangan keuangan syar'ah. Selain itu, bersama Qatar, Saudi Arabia, Malaysia UAE, Turki yang tergabung dalam (QISMUT), Indonesia dianggap sebagai kekuatan pendorong keuangan syariah di masa depan. ${ }^{21}$

Dalam skala nasional perbankan syariah masih terus tumbuh, menurut data terakhir Maret 2016 Jumlah Bank Umum Syariah berjumlah 12, Unit Usaha Syariah berjumlah 22, Jumlah

20 Otoritas Jasa Keuangan, Modul Training of Trainers Keuangan Syariah (Roadmap Perbankan Syariah Indonesia 2015 2019) h.108

21 Ibid. h. 108 
BPRS berjumlah 165, Jumlah jaringan Kantor (BUS dan UUS) berjumlah 2.230. Belum lagi ditambah dengan pertumbuhan lembaga keuangan syariah non bank seperti asuransi syari'ah, Baitul Mal wa Tamwil (BMT) dan pegadaian syaria'ah. ${ }^{22}$

Meningkatnya pertumbuhan lembaga keuangan syari'ah di Indonesia secara otomatis mengharuskan adanya penguatandari sisiprinsip syariah, agar perjalanan lembaga keuangan syariah selalu dalam track yang benar dan seiring mengikuti kaidah-kaidah syariah yang berlaku, serta mampu menepis persepsi masyarakat yang beranggapan lembaga keuangan syariah hanya label namanya "syariah" tetapi produk dan isinya tidak jauh berbeda dengan konvensional.

Untuk menjaga produk-produk perbankan syariah dan mensterilkan dari hal-hal yang dilarang membutuhkan penguatan prinsip-prinsip syariah yang diambil dari sumber ajaran Islam yaitu al-Qur'an, Sunnah, Ijma, dan Ijtihad Ulama yang terkodifikasi dalam berbagai literatur yang dikaji oleh ulama atau perkumpulan ulama dalam Dewan Syariah baik dalam skala Internasional dan Nasional. Sehingga perkembangan dan pertumbuhan lembaga keuangan syariah selaras dengan prinsip-prinsp syariah. Karena prinsip syari'ah adalah salah satu karakeristik dan pembeda bank syariah dari bank lainnya.

Salah satu fungsi bank syariah adalah menghimpun dana dari masyarakat, untuk simpanan jasa tabungan dan giro bank syariah menggunakan akad wadi'ah (titipan). Penggunaan akad ini apakah sudah tepat? atau ada akad lain yang lebih tepat dan sesuai dengan karakteristik produk giro dan tabungan. Untuk deposito menggunakan prinsip mudharabah. Dalam penerapakan prinsip ini apakah sudah sesuai atau masih kegiatan operasional yang menyalahi akad tersebut.

\section{Identifikasi Masalah}

Penulis mengindentifikasikan masalah sebagai rumusan masalah yang perlu dikaji adalah sebagai berikut :

a. Apa pengertian bank syariah?

b. Seberapa pentingnya prinsip syariah dalam produk bank Syariah?

c. Jelaskan prinsip umum dalam bank syariah?

d. Bagaimana keselarasan akad wadi'ah sebagai salah satu produk bank syariah?

e. Bagaimana keselarasan akad Mudhorabah sebagai salah satu produk bank syariah?

\section{Metode Penulisan}

Dalam kajian ini dengan mengharap pertolongan dari Allah Subhanahu wa Ta'ala mencoba menelaah dan mengkaji aspek prinsip hukum syariah terhadap produk-produk di perbankan syari' ah, sekaligus menganalisa beberapa hal yang bertentangan dengan prinsip-prinsip syari' ah. Dalam kajian ini penulis membatasi pada produk perbankan syariah yang menggunakan prinsip wadi'ah dan mudharabah.

Kajian ini menggunakan kajian pustaka dengan mengambil referensi yang orisinil dari bahasa Indonesia dan Arab. Pendekatan yang penyusun gunakan dalam tulisan ini adalah pendekatan deduktif yaitu suatu cara pendekatan terhadap masalah yang diteliti dengan mengkaji dan menelaah dari kaidah-kaidah syariah dan diaplikasikan pada prinsip yang berkembang di perbankan syari'ah.

\section{Pembahasan}

\section{Definisi Perbankan Syariah}

Kata bank berasal dari bahasa Italia banco yang artinya bangku. ${ }^{23}$ Bangku inilah yang dipergunakan oleh bankir untuk melayani kegiatan operasionalnya kepada para nasabah.

Pada Abad ke-12 kata banco di Italia merujuk pada meja, counteratau tempat usaha penukaran uang (money changer). Arti ini menyiratkan fungsi transaksi yaitu penukaran uang

22 Ibid. h. 112

23 Thomson's Dictionary of Bankin, London : The New Era Publishing Co.Ltd., 11th ed., p.45, Bank. 
atau dalam arti transaksi bisnis yang lebih luas yaitu membayar barang dan jasa. ${ }^{24}$ Kemudian istilah ini digunakan sampai saat ini yang menggambarkan tempat transaksi antara bank dan nasabah dengan berbagai produk dan jasa yang ditawarkan.

Dr. Husein Syahatah menjelaskan definisi bank syariah adalah lembaga keuangan syariah yang membuka layanan produk perbankan dan keuangan, investasi dalam berbagai sektor sesuai dengan kaidah syariah dan bertujuan merealisasikan pertumbuhan sosial dan ekonomi umat Islam..$^{25}$

Menurut UU No. 7 tahun 1992 yang direvisi dengan UU Perbankan No. 10 Tahun 1998 mendefinisikan bank syariah adalah : lembaga keuangan yang pengoperasiannya dengan sistem bagi hasil.

Dalam UU No.21 tahun 2008 mengenai Perbankan Syariah mengemukakan pengertian perbankan syariah dan pengertian bank syariah. Perbankan Syariah yaitu segala sesuatu yang menyangkut bank syariah dan unit usaha syariah, mencakup kelembagaan, mencakup kegiatan usaha, serta tata cara dan proses di dalam melaksanakan kegiatan usahanya.

Bank Syariah adalah bank yang menjalankan kegiatan usahanya dengan didasarkan pada prisnsip syariah dan menurut jenisnya bank syariah terdiri dari BUS (Bank Umum Syariah), UUS (Unit Usaha Syariah) dan BPRS (Bank Pembiayaan Rakyat Syariah).

Dari definisi di atas dapat disimpulkan yang dimaksud dengan bank syariah adalah lembaga keuangan yang seluruh aturan dan transaksinya mengikuti prinsip-prinsip syariah. Maka dalam operasional bank syariah sangat ditentukan oleh prinsip-prinsip syariah, tidak boleh sedikitpun ada produknya yang bertentangan dengan syariah.

\section{Keniscayaan Prinsip Syariah dalam produk perbankan Syariah}

Allah Subhanahu wa Ta'alamelalui wahyu-Nya al-Qur'an dan Hadits telah menjelaskan prinsip-prinsip syariah dalam setiap transaksi yang dilakukan hamba-Nya, berfungsi sebagai rambu-rambu manusia dalam setiap transaksinya sehingga dapat terhindar dari praktek yang syubhat dan yang diharamkan Allah Swt.

Sebagaimana firman Allah, QS. Al-Nisa (4) : 29 :"Wahai orang-orang yang beriman! Janganlah kamu saling memakan harta sesamamu dengan jalan yang batil (tidak benar), kecuali dengan jalan perdagangan yang berlaku atas dasar suka sama-suka di antara kamu. Dan janganlah kamu membunuh dirimu. Sesungguhnya Allah Maha Penyayang kepadamu.

Dalam hal ini Rasululullah di dalam haditsnya yang diriwayatkan Abu Hurairah Rădiyallahu "Anhu bersabda, "Akan datang kepada manusia suatu masa, di mana orang tidak lagi peduli tentang apa dan bagaimana sesuatu yang diperolehnya, apakah dari yang halal ataukah dari yang haram" (HR. Bukhari).

Penjelasan dari Al-Qur'an dan Hadits tersebut mengisyaratkan pentingnya kehati-hatian dalam melakukan berbagai transaksi, dan pentingnya mengetahui hukum dan prinsip syariah pada setiap transaksi baik dalam skala makro maupun dalam skala mikro. Karena setiap transaksi yang salah dan haramberimplikasi kepada tidak sahnya sebuah akad, dan ketika sebuah akad tidak sah akan mendapat dosa yang harus ditanggung pelakunya, dan menyebabkan kerugian dan kesengsaraan di dunia dan di akhirat. Bahkan akan berpengaruh kepada karakter dan akhlak keturunannya, karena harta diperoleh dengan cara yang halal akan mengalir dengan kebaikankebaikan, sebaliknya harta yang didapatkan dengan cara yang tidak baik akan mengalirkan keburukan-keburukan.

Bandingkan dengan teori perusahaan yang dikembangkan selama ini di Indonesia menekankan pada prinsip memaksimalkan keuntungan. Walaupun harus bertentangan prinsip syariah atau aturan sebuah adat. Etika dan norma sudah tidak diperdulikan, yang ada bagaimana

24 Zainul Arifin, Dasar-Dasar Manajemen Bank Syariah, Jakarta: Azkia Publisher., April 2009, h. 2

25 Husein Syahatah, al-Masharif al-Islamiyah Baina al-Fikr wa at-Tathbiq, Cairo : Dar al-nasr Lil jami'at., 2009 h. 28 
melejitkan keuntungan sebesar-besarnya.

Bank Syariah adalah bagian dari tatanan ekonomi Syariah, maka komitmennya adalah patuh terhadap prinsip dan etika agama yang telah dijelaskan dalam al-Qur'an dan Hadits, di antaranya ada yang bersifat umum seperti kegiatannya harus selalu mengacau kepada konsep maslahat dan menjungjung tinggi asas-asas keadilan. Karena tujuan Ekonomi Syariah secara umum adalah mencapai falah di dunia dan akhirat, larangan memakan dengan cara yang batil sebagaimana dalam QS. (An-Nisa : 29), Selalu bertransaksi dengan hal-hal yang baik QS. (AlBaqarah : 168), Menjauhi hal-hal yang diharamkan QS. (Al-Maidah : 90), dan berinteraksi dengan seluruh manusia dengan cara yang baik QS. (Al-Baqarah :83). Ataupun prinsip khusus dan terperinci seperti larangan riba, gharar, qimar dan prinsip lain yang berkaitan dengan produk bank syariah.

Untuk merealisasikan tujuan mulia dan cita-cita besar ekonomi syariah, lembaga keuangan syariah sebagai bagian dari ekonomi syariah dapat memastikan semua produk-produk yang dihasilkan adalah sesuai dengan prinsip yang di atur oleh syariah. Tujuannya tidak hanya mendapatkan keuntungan materi saja, tetapi mendapatkan keuntungan secara spiritual yang tertuang dalam keberkahan dalam semua transaksinya.

\section{Prinsip Syariah Terkait Produk Perbankan Syariah}

Secara umum di antara prinsip-prinsip terkait produk perbankan syariah adalah usaha yang menjauhi praktek riba, gharar, Maisir dan Produk yang haram. Untuk memperjelas empat unsur tersebut akan dijelaskan pengertian, landasan hukum dan pembagiaanya. Diharapkan dengan memahami prinsip ini, secara aplikatif bank syariah betul-betul menjaga dari unsur tersebut.

\section{Riba}

Salah satu prinsip fundamental terkait produk-produk perbankan syari'ah adalah menjauhi riba dalam segala transaksinya. Perbedaan utama lembaga keuangan syariah dengan lainnya semua produk-produknya steril dari masalah riba. Secara etimologis riba dari kata rabă asyaiu yarbŭ robwan ribaanberarti zăda (bertambah) dan namă (berkembang). ${ }^{26}$

Menurut Abdul Ghofur Anshori, istilah riba berasal dari kata r-b-w, yang digunakan dalam al-Qur'an sebanyak dua puluh kali. Di dalam Al-Qur'an riba dapat dipahami dalam delapan arti, yaitu : pertumbuhan (growing), peningkatan (inceasing), bertambah (swelling), meningkat (rising), menjadi besar (being big) dan besar (great), dan juga diartikan bukit kecil (hillock). Dengan kata lain, riba artinya tumbuh dan membesar. ${ }^{27}$ Walaupun riba diartikan tambahan, tetapi tidak semua yang bertambah itu riba menurut hukum fikih.

Sedangkan secara terminologis riba menurut ulama adalah sebagai berikut :

a. Menurut Ulama Hanafiah, riba adalah kelebihan tanpa ada pengganti dan disyaratkan dalam transaksi jual beli. ${ }^{28}$

b. Menurut ulama Syafi'iyah, riba adalah bentuk transaksi dengan cara menetapkan pengganti tertentu (yang tidak diketahui kesamaanya dengan yang ditukar) dalam ukuran syariat pada saat transaksi, atau disertai penangguhan terhadap kedua barang yang dipertukarkan ataupun terhadap salah satunya. ${ }^{29}$

c. Menurut Ulama Hanabilah, riba adalah pertambahan sesuatu yang dikhususkan. ${ }^{30}$

d. Dari definisi di atas ada beberapa pendapat dalam menjelaskan riba, namun secara umum terdapat benang merah yang menegaskan bahwa riba adalah pengambilan tambahan di atas modal yang dilarang Allah Subhanahu wa ta'ala.

26 Ibnu Manzdur, Lisănul Arab, (Kairo : Dăr al-Hadits,2003) Vol. 4 h. 54-55 Materi (R-B-W)

27 Abdul Ghofur Anshori, Aspek Hukum Reksa Dana Syariah di Indonesia, (Bandung : Refika Adiama, 2008), h. 11

28 Sarkhasi, al-Mabsuth (Beirut : Dar al-Ma'rifat) Vol. 12 h. 109

29 Syarbini, Mughni al-muhtaj(Beirut, Dar al-Fikr) Vol. 2 h. 21

30 Ibnu Qudamah, al-Mughni, (Kairo, Dar al-Kitab al-Arobi) Vol. 4 h. 122 


\section{Dasar Hukum Keharaman Riba}

Riba termasuk tujuh dosa besar yang menghancurkan. Di antara dasar pelarangan riba adalah Dasar pelarangan riba adalah Al-Qur'an, Sunnah, Ijma.

a. Al-Qur'an

Perintah untuk meninggalkan riba di dalam al-Qur'an diturunkan secara bertahap. Di awali dari QS. Ar-Rum (30) : 39, kemudian QS. An-Nisa (4) : 161 dilanjutkan dengan QS. Ali-Imran (3) : 130 dan terakhir secara dalam QS. Al-Baqarah (2) : 275-276 dengan jelas Allah mengharamkan riba, Allah Swt berfirman : "Orang-orang yang makan (mengambil) riba tidak dapat berdiri melainkan seperti berdirinya orang yang kemasukan syaitan lantaran (tekanan) penyakit gila. Keadaan mereka yang demikian itu, adalah disebabkan mereka berkata (berpendapat), sesungguhnya jual beli itu sama dengan riba, padahal Allah telah menghalalkan jual beli dan mengharamkan riba. Orang-orang yang telah sampai kepadanya larangan dari Tuhannya, lalu terus berhenti (dari mengambil riba), maka baginya apa yang telah diambilnya dahulu (sebelum datang larangan); dan urusannya (terserah) kepada Allah. Orang yang kembali (mengambil riba), maka orang itu adalah penghuni-penghuni neraka; mereka kekal di dalamnya".

Ayat di atas menggambarkan orang-orang yang makan riba akandibangkitkan dari kuburnya pada hari kiamat nanti melainkan seperti orang gila yang terbangun pada saat mendapat tekanan penyakit dan setan merasukinya. Hal ini menunjukkan bahwa kondisi mereka sangat buruk. ${ }^{31}$ Gambaran ini menunjukkan larangan kita melakukan riba dengan berbagai bentuk dan sedikit mapun banyak.

b. Hadits

Rasulullah shallallahu 'alaihi wasallam melaknat orang yang memakan riba, memberi makan riba (orang yang memberi riba kepada pihak yang mengambil riba), juru tulisnya, dan dua saksinya. Beliau mengatakan: 'Mereka itu sama'.” [HR. Muslim]

Dari Abu Hurairah Radiallahu Anhu dari Nabi Shallahu "Alahi wa Salam beliau bersabda : " Jauhilah oleh kalian tujuh hal yang menyebabkan kebinasaan." Kami (para shahabat) bertanya: "Apa tujuh hal itu, wahai Rasulullah?" Beliau menjawab: "...memakan (mengambil) riba...”[HR. Al-Bukhari dan Muslim].

c. Ijma'

Para ulama dari dulu sampai saat inidiseluruh duniasepakat telah mengharamkan riba.Bunga bank adalah bagian riba. Dr. Yusuf Qardhawi mengungkapkan bahwa telah lahir ijma ulama dari berbagai lembaga, pusat penelitian, muktamar, seminar-seminar ahli fikih dan ahli ekonomi Islam yang mengharmkan bunga bank dalam segala bentuknya, dan bunga bank ada riba. ${ }^{32}$

Filosofi riba diharamkan karena mendatangkan dampak negatif terhadap individu, sosial bahkan berpengaruh dari sisi ekonomi. Secara individu menyebabkan sifat rakus dan mengambil hak orang lain, karena praktek riba mengambil harta kawannya tanpa ganti. Sebab orang yang meminjamkan uang 1 dirham dengan 2 dirham, maka dia dapat tambahan satu dirham tanpa imbalan ganti. ${ }^{33}$

Secara sosial menghilang sifat tolong menolong dan solidaritas di kalangan masyarakat, karena riba akan menyebabkan terputusnya sikap yang baik (ma'ruf) dalam hal pinjam-meminjam. Sebab kalau riba itu diharamkan, maka seseorang akan merasa senang meminjamkan uang satu dirham dan kembalinya satu dirham juga. Tanpa berharap ada tambahan apapun. Inilah yang bisa menumbuhkan masyarakat untuk selalu berbagi dan sepenanggungan.

31 Muhammad Ali Shobuni, Tafsir Ayat Ahkam, (Beirut : Dar al Kutub Ilmiyah) cet. I Vol.I h.272-273

32 Yusuf Qardhawi, Fawaidh al-Bunuk Hiya Riba (Jakarta : Usamah Press, 2000), h.83

33 'Aid Fadl al-Sya'rowi, Al-Masyarif Al-Islamiyah Dirosah Ilmiyah Fiqhiyah lil Mumarosat Al-Amaliyah (Damaskus : Dar al-basyair al-Islamiyah) h.40 
Sedangkan secara ekonomi riba telah membunuh semangat berinvestasi, Karena orang lebih nyaman menyimpan uang dengan mendapatkan kepastian bunga, tidak mau berinvestasi yang memiliki resiko untung dan rugi. Sehingga proyek produk barang juga semakin menurun, pekerjaan pun semakin terbatas.

Riba (bunga) telah jelas diharamkan oleh syariah Allah dan secara nyata dapat merusak tatanan individu, sosial bahkan ekonomi. Maka prinsip menjauhkan riba harus menjadi ciri yang melekat dalam setiap transaksi bank syariah. Pihak bank melalui dewan syariah harus memastikan setiap produk, jasa dan transaksinya terhindari dari unsur riba. Tidak hanya menjadi jargon atau label sebagai bank bebas bunga, tetapi juga secara praktik steril dari riba.

Pembagian Riba

Ulama berbeda pendapat terkait pembagian riba, ada yang membagi menjadi riba qardh, nasi' ah dan fadl, ada yang membagi menjadi riba yang jelas (jali) dan riba yang samar (khofi), tetapi jika kita merujuk pada dalil-dalil al-Qur'an dan Sunnah bisa disimpulkan riba terbagi menjadi riba qardhatau riba jahiliyah dan riba buyu'Riba buyu' mencakup riba fadl dan riba nasi'ah.

Riba qardh adalah riba yang terjadi pada transaksi utang-piutang yang tidak memenuhi kriteria untung muncul bersama risiko dan hasil usaha muncul bersama biaya. Transaksi semisal mengandung pertukaran kewajiban menanggung bebas, hanya karena berjalannya waktu. $^{34}$

Di antara contoh riba qardh pada produk perbankan adalah pembayaran bunga deposito, tabungan, giro dan lainnya. Makanya dalam produk perbankan syariah melarang seluruh pembayaran dengan bunga.Karena pembayan bunga adalah riba, sedangkan riba diharamkan oleh Allah Swt.

\section{Gharar}

Secara etimologis gharar adalah al-khathr (pertaruhan). Sehingga Imam Jurjani menyatakan, gharar adalah yang tidak jelas hasilnya (majhul al-'aqibah) tidak tahu apakah ada atau tidak. ${ }^{35}$ Sedangkan menurut terminologi ada beberapa pandangan di antaranya ;

Menurut Imam Syarkhasi dari ulama hanafiyah mengatakan : Sesuatu yang tidakjelas hasilnya.Sedangkan Imam malik mendefinisikan gharar sebagai jual beli objek yang belum ada, belum diketahui kualitas barang itu baik atau buruk oleh pembeli, seperti ; jual beli binatang yang telah lepas dari tangan pemiliknya, atau jual beli anak binatang yang masih berada dalam kandungan ibunya ${ }^{36}$ Menurut UU No. 21 Tahun 2008 tentang Perbankan Syariah, ghararyaitu transaksi yang objeknya tidak jelas, tidak dimiliki, tidak diketahui keberadaanya, atau tidak dapat diserahkan pada saat transaksi dilakukan kecuali diatur lain dalam syariah. ${ }^{37}$

Dari pengertian di atas bisa disimpulkan bahwa gharar adalah keraguan dalam keberadaan obyek akad transaksi seperti dalam kualitas, kuantitaas, harga atau hal yang tidak jelas hasilnya atau pertaruhan yang menimbulkan keraguan antara baik dan buruk.

\section{Dasar Hukum Gharar}

GhararmenurutPrinsip Islam adalah dilarang. Dengan dasar hadits Rasulullah Saw., bahwa Abu Hurairah mengatakan Rasulullah shallallahu 'alaihi wa sallam melarang jual beli al-hashah (jual beli dengan cara lempar batu) dan jual beli gharar."

34 Adiwarman Karim, Bank Islam ; Analisis Fikih dan Keuangan, (Jakarta : RajaGrafindo Persada, 2014), edisi III, h. 37.

35 Ali Jurjani, Al-Ta'rifat(Beirut : Dar al-Kitab al-Arobi,1405 H.) Cet.Ih.208.

36 Sutan Remy Sjahdeni, Perbankan Syariah: Produk-Produk dan Aspek-Aspek Hukumnya (Jakarta: Kencana, 2014), h. 169

37 Penjelasan Pasal 2 UU No. 21 Tahun 2008 tentang Perbankan Syariah. 
Dalam sistem gharar ini terdapat unsur memakan harta orang lain dengan cara batil. Padahal Allah melarang memakan harta orang lain dengan cara batil.

Filosofi larangan gharar adalah adanya pertaruhan dan menimbulkan sikap permusuhan pada orang yang dirugikan. Yakni bisa menimbulkan kerugian yang besar kepada pihak lain. Larangan ini juga mengandung maksud untuk menjaga harta agar tidak hilang dan menghilangkan sikap permusuhan yang terjadi pada orang akibat jenis jual beli ini. ${ }^{38}$

\section{Jenis Gharar}

Ulama berbeda pendapat terkait pembagian gharar, ada yang membagi menjadi tiga, ada juga yang membagi menjadi empat bahkan ada yang membagi menjadi 10 bagian. Tetapi secara umum dapat ditinjau dari dua sisi ;

a. Gharar dalam akad transaksi, yaitu ghararyang terjadi karena ada unsur akadnya tidak ada kejelasan, seperti saya jual rumah ini kepada A, dengan syarat si A menjualkan rumahnya kepada saya.Ungkapan ini jelas mengandung gharar karena mengungkapan sesuatu yang tidak jelas.

b. Gharar dalam objek transaksi, yaitu Gharar yang terjadi karena unsurnya obyeknya (jenis, sifat, ukuran) yang tidak jelas transaksi. Seperti orang yang menjual barang secara online tanpa menyebut bentuk fisik barang, sifat barang, ukurannya, apalagi kalau tidak dapat diserahterimakan atau barang bukan milik penjual. ${ }^{39}$

\section{Kriteria Gharar}

Salah satu prinsip syariah yang harus dihindari oleh bank syariah adalah tidak ada unsur gharar di dalam transaksinya. Untuk memastikan kriteria gharar yang diharamkan, karena tidak semua gharar di larang, di antara kriterianya adalah ;

a. Gharar dalam kuantitas yang banyak menyebabkan ketidakabsahan sebuah kontrak, berbeda dengan gharar dalam kuantitas yang sedikit masih diperbolehkan.

b. Kemudian akad terjadi pada akad-akad komersial seperti jual beli, sewa menyewa dan lain sebagainya. Berbeda dengan akad yang bersifat sosial dibolehkan ada unsur ghararnya.

c. Tidak masuk kategori akad yang diperlukan (Hajat) oleh banyak orang. Jika dalam akad tersebut termasuk yang dibutuhkan apalagi sangat dibutuhkan maka tidak berlaku adanya hukum gharar. ${ }^{40}$

Di antara praktek kontemporer yang mengandung unsur gharar adalah short selling, yaitu suatu cara yang digunakan dalam penjualan saham yang belum dimiliki dengan harga tinggi dengan harapan akan membeli kembali pada saat harga turun. ${ }^{41}$

\section{Maisir}

Secara etimologis maisir artinya hewan yang disembelih dan dipotong menjadi beberapa bagian, kebiasaan orang jahiliyah daging tersebut dijadikan tempat sasaran panah, jika tepat sasaran dia berhak mendapatkan dagingnya. ${ }^{42}$ Maisir dalam istilah lain adalah qimar, artinya bertaruh (dalam perjudian) artinya memperolehi sesuatu dengan mudah atau tanpa usaha. ${ }^{43}$

38 IbnuTaimiyah :Kutub wa Rasa 'ilwa Fatawa Syekhul Islam IbnuTaimiyah (Kairo : IbnuTaimiyah). Vol. 29.h. $22-23$

39 Dr. Shiddiq Muhammad Amin Dhorir, al-Ghoror fil al-Uqud (Jedah : Bank Islami Li Tanmiyah, 1993) h.18

$40 \quad$ Ibid, h.40

41 Fatwa DSN no: 80/DSN-MUI/III/2011 tentang penerapan prinsip syariah dalam mekanisme perdagangan efek bersifat ekuitas di pasar reguler Bursa Efek.

42 Nasr Muhammad Sulami, Dhowabith Syar'iyah Lil-Istitsmar (Iskandariyah: Dar al-Iman, 2008) h. 304.

43 Ibnu Manzdur, Op.cit., vol. 5 hlm 115. 
Sedangkan secara terminologis Maisir adalah Setiap harta yang diperoleh dengan spekulasi. ${ }^{44}$ Menurut UU No. 21 Tahun 2008 tentang Perbankan Syariah, maisir adalah transaksi yang digantungkan kepada suatu keadaan yang tidak pasti. ${ }^{45}$

Dari definisi di atas dapat ditarik kesimpulan, maisir (perjudian) adalah usaha mendapatkan harta tanpa susah payah dan cara mendapatkan harta dan sebab menjadi kaya (berkecukupan).

Pengharaman Maisir

Maisir (perjudian) terlarang dalam syariat Islam, dengan dasar al-Quran, Sunnah, dan ijma'. Dalam QS. Al-Maidah : 90 Allah berfirman yang artinya :"Wahai orang-orang yang beriman, sesungguhnya (meminum) khamar, berjudi, (berkorban untuk) berhala, mengundi nasib dengan panah, adalah termasuk perbuatan syaitan. Maka, jauhilah perbuatan-perbuatan itu agar kamu mendapat keberuntungan.

Ayat tersebut dengan jelas mengharamkan berjudi bahkan masuk kategori perbuatan syetan. Maka sudah seharusnya hal tersebut dijauhkan dalam semua transaksi.

Dalam hadits Rasulullah SAW. bersabda :"Barangsiapa yang menyatakan kepada saudaranya, 'Mari, aku bertaruh denganmu.' maka hendaklah dia bersedekah." (HR. Bukhari dan Muslim)

Dalam hadits ini, Nabi shallallahu 'alaihi wa sallam menjadikan ajakan bertaruh-baik dalam pertaruhan atau muamalah-sebagai sebab membayar kafarat dengan sedekah, Ini menunjukkan keharaman pertaruhan. Demikian juga, sudah ada ijma' tentang keharamannya.

\section{Menghindari produk yang diharamkan}

Prinsip syariah lainnya adalah menghindari produk yang diharamkan Allah Subhanu wa Ta'la seperti minuman keras, babi alat-alat musik yang dapat menjauhkan kedekatan dengan Allah dan menghambur-hamburkan uang. Serta hal-hal yang dapat merusak agama, akal, jiwa, harta dan harga diri manusia.

Banyak hadits-hadits yang mengharamkan tentang produk yang dilarang. Rasulullah Shallallahu 'Alaihi wa Salam telah melarang menjual bangkai, khamr, babi, patung. Barang siapa yang menjual bangkai maksudnya daging hewan yang tidak disembelih dengan cara yang syar'i berarti telah menjual bangkai dan memakan hasil yang haram.

Maksud khamr adalah segala yang bisa memabukkan. Rasulullah melaknat sepuluh orang yang berkaitan dengan khamr. "Sesungguhnya Allah melaknat Khamr, pemerasnya, yang minta dipersakan, penjualnya, pembelinya, peminum, pemakan hasil penjualannya, pembawanya, orang yang minta dibawakan serta penunganya. (HR. Tirmizdi dan Ibnu Majah)

Termasuk dalam masalah ini, bahkan lebih berat lagi hukumnya yaitu menjual narkoba, ganja, opium dan jenis obat-obat psikotropika lainnya yang merebak pada saat ini. Semua produk yang dijual bank syariah harus terhidar dari produk yang diharamkan.

\section{a. Prinsip Syariah Terhadap Produk Bank Syari’ah}

Bank syariah merupakan salah satu lembaga keuangan yang menjalankan kegiatannya sesuai dengan prinsip-prinsip syariah. Secara umum aktivitas bisnis diperbankan syariah meliputi tiga sisi. sisi pertama yaitu penghimpunan dana (Funding), sisi kedua adalah penggunaan dana (Financing). Sedangkan sisi yang terakhir adalah jasa (Service). ${ }^{46}$

Dalam kajian ini penulis membatasi prinsip syariah pada penghimpunan dana seperti prinsip wadi'ah dalam simpanan deposito dan tabungan,prinsip mudharabah dalam deposito.

44 Nasr Muhammad Sulami, Op. cit., h. 304.

45 Penjelasan Pasal 2 UU No. 21 Tahun 2008 tentang Perbankan Syariah.

46 Adiwarman A. Karim, Bank Islam Analisis Fiqih dan Keuangan, Jakarta: Grafindo Persada, 2008. Cet ke-.3 h.97 


\section{b. Prinsip Wadi'ah TerhadapProduk Giro dan Tabungan}

Wadi'ah secara etimologi berarti menempatkan sesuatu yang ditempatkan bukan pada pemiliknya, bentuk plural wadia'ah adalah wada'i. Sedangkan secara terminologi wadi'ah adalah transaksi yang menempatkan sesuatu untuk dipelihara atau barang titipan yang dijaga. ${ }^{47}$

Menurut Kompilasi Hukum Ekonomi Syari'ah wadi'ah adalah penitipan dana antara pihak pemilik dana dengan pihak penerima titipan yang dipercaya untuk menga dana tersebut. ${ }^{48}$

Secara umum yang dimaksud dengan giro adalah simpanan yang penarikannya dapat dilakukan setiap saat dengan menggunakan cek, bilyet giro, sarana perintah bayar lainnya, atau dengan pemindahbukuan. ${ }^{49}$ Giro dapat dibuka oleh perusahaan atau perorangan, dan akan diberikan bonus atau pemberian sukarela. Giro hanya boleh dilakukan oleh bank umum (Bank Umum Konvensional), Bank Umum Syariah atau Unit Usaha Syariah dan tidak boleh dilakukan oleh Bank Perkreditan rakyat ataupun Bank Pembiyaan Rakyat Syariah.

Tabungan adalah simpanan yang dapat diambil berdasarkan kesepakatan dengan menggunakan buku atau kartu sebagai alat penarikan dan diberikan imbalan bagi hasil atau bonus.Sedangkan deposito adalah simpanan untuk jangka waktu tertentu yang dapat diambil setelah jatuh tempo, menggunakan bilyet sebagai tanda bukti simpanan dan diberikan imbalan berupa bagi hasil yang dibayarkan tiap akhir bulan.

Dalam prakteknya, bank syari'ah memberikan jasa simpanan giro dan tabungan berdasarkan prinsip/akad wadi'ah yad dhamanah. Dengan prinsip ini bank sebagai custodian harus menjamin pembayaran kembali nominal simpanan wadi'ah. Dana tersebut dapat digunakan oleh bank untuk kegiatan komersial. Pemilik simpanan dapat menarik kembali simpanannya sewaktu-waktu, baik sebagian atau seluruhnya. ${ }^{50}$

Maka dalam produk simpanan giro dan tabungan ini,pihak bank maupun nasabah sama-sama mendapatkan keuntungan. Bank syariah sebagai penerima titipan mendapatkan kucuran dana dari nasabah dan dapat digunakan untuk kegiatan komersil, sedangkan nasabah sebagai pemberi titipan mendapatkan jaminan keamanan dananya dari kehilangan ataupun pencurian. Dan juga mendapat kemudahan untuk mengambil dana tersebut saat membutuhkan.

Akan tetapi, Bank Syariah tidak boleh menyatakan atau menjanjikan imbalan atau keuntungan apa pun kepada pemegang rekening wadi'ah, dan sebaliknya pemegang rekening juga tidak boleh mengharapkan atau meminta imbalan atau keuntungan atas rekening wadi'ah. Setiap imbalan atau keuntungan yang dijanjikan dapat di anggap riba. Namun demikian bank, atas kehendaknya sendiri, dapat memberikan imbalan berupa bonus (hibah) kepada pemilik dana (pemegang rekening wadi'ah). ${ }^{51}$

Karena tujuan Giro dan Tabungan adalah menyimpan bukan investasi, maka konsekuensinya adalah pihak bank syariah tidak memberikan keuntungan dari perputaran uangnya tetapi justru mengharuskan nasabah untuk membayar administrasi sesuai ketentuannya. Maka akad yang digunakannya adalah wadi'ah.

Penerapan prinsip wadi'ahdalam simpanan giro diperkuat oleh fatwa Dewan Syariah Nasional (DSN) No. 01/DSN-MUI/IV/2000: "Giro yang dibenarkan secara syariah yaitu giro yang berdasarkan prinsip mudharabah dan wadiah”.Dan Fatwa no. 02/DSN-MUI/

47 Sa’di Abu Habib, Qamus al-Fiqhi Lughatan wa Istilahan. Damaskus : Dar al-Fikri 1982, cet. Ke 1 h. 376.

48 Pasal 20 angka (17) Kompilasi Hukum Ekonomi Syariah.

49 Undang-undang Republik Indonesia Nomor 10 tahun 1998 tentang perubahan atas undang-undang nomor 7 tahun 1992 tentang perbankan.

50 Zainul Arifin, Dasar-Dasar Manajemen Bank Syariah,Jakarta: Azkia Publisher, April 2009, hlm.61-62

51 Ibid. 
IV/2000 tentang tabungan. Konsekuensi pendapat ini bahwa pihak yang menerima titipan (bank) boleh memberi hadiah berbentuk barang atau uang kepada pemilik dana dan hadiah itu hukumnya halal sebagaimana difatwakan DSN tentang ketentuan umum giro wadiah: "Tidak ada imbalan yang disyaratkan, kecuali dalam bentuk pemberian ('athaya) yang bersifat suka rela dari pihak bank". Yang menjadi dasar pendapat ini adalah niat nasabah menitipkan uangnya dan ia dapat menarik uangnya kapan ia butuh. Ini tak ubahnya wadiah (titipan barang) dalam tinjaun fikih.

Dari uraian tersebutapakah ada keselarasan antara praktek simpanan dan giro dengan akadwadiah ? Karena menurut mayoritas ulama dari Mazhab Hanafiyah ${ }^{52}$, Syafi'iyah ${ }^{53}$ dan Hanabilah $^{54}$ yang berpendapat haram memanfaatkan dana yang dititipkan.Hanya pendapat malikiyah yang mengatakan makruh, itupun harus ada kepastian dapat mengganti barang yang dititipkan ${ }^{55}$.

Dengan pertanyaan ini barangkali kita mencari jawaban dan alternatife penggunaan akad yang tepat dalam praktek simpanan giro dan tabungan, karena fiqih kaya dengan ragam pendapat dan kaidah.Ada prinsip akad Qord yang bisa digunakan sebagai akad dalam titipan giro dan tabungan, dan sudah banyak ulama yang menjelaskan persoalan ini.

Di antara ulama kontemporer juga mengatakan bahwa produk giro dan tabungan dalam fikih termasuk akad hutang (Al-Qordu) di antaranya adalahDr. Husain Syahatah, beliau berpendapat bahwa titipan Giro dan Tabungan pada hakikatnya adalah Qordu Hasan (pinjaman tanpa bunga).Pihak bank diberikan izin untuk mengelola dan menjamin ketersedian dana ketika dibutuhkan. ${ }^{56}$ Dan pendapat ini juga didukung oleh Dr. Muhammad Ali Salus, Dr. Abdu Sami al-Misry, Dr. Ahmad bin Hasan al Hasani dan lain sebagainya.

Di antara argumentasi yang mengatakan simpanan giro dan tabungan adalah akad Qord lebih tepat, pada praktek simpanan giro pihak bank memanfaatkan simpanan tersebut untuk diinvestasikan karena kepemilikanya berpindah dan pihak bank berkewajiban mengembalikan simpanan tersebut dengan jumlah yang sama. Sedangkan dalam akad wadi'ah tidak ada hak bank untuk mengelola simpanan tersebut, jika simpanan itu hilang atau rusak tanpa ada unsur kesengajaan maka pihak bank tidak ada kewajiban mengganti simpanan tersebut. ${ }^{57}$

Argumentasi lainnya, bahwa dalam akad wadi'ah memiliki konsekuenensi yang berbeda dengan yang terjadi dalam praktek simpanan di bank. Walaupun memiliki kesamaan terkait syarat kewajiban menjaga simpanan nasabah dan mengembalikan ketika diminta, tetapi mereka berbeda ketika dalam hal permintaan izin bank kepada nasabah untuk mengelola atau mencampurkan dananya untuk diinvestasikan, padahal dalam prinsip wadi'ah menurut fiqih tidak boleh dana simpanan (wadi'ah) dikelola dan diinvestasikan kecuali dengan izin pemiliknya.

Argumentasi lain yang menguatkan pendapat ini adalah pendapat dari Mazhab Malikiyah yang mengatkan bahwa orang yang menerima amanah wadi'ah jika menerima izin dari pemiliknya untuk memanfaatkan simpanan tersebut maka hukumnya seperti AlQord (Utang)..$^{58}$

52 Sarkhasi, al-Mabsuth, Beirut: Dar a-Ma'rifat 1406 H., Vol. 11 hlm. 112

53 Muhammad bin Idris Asy-Syafi'I, al-Um., Beirut : Dar al-Ma'rifat, 1393 H., cet. II vol. 4 hlm.143

54 Ibnu Muflih, al-Furu'., Beirut : Dar al-Ma'rifat, Vol.4 hlm.275

55 Abu Abdullah Muhammad bin Yusuf Al-Abadri, Al-taj wa Al-Iklil Li Mukhtasor Kholil, Beirut : Dar al-Kutub al-Ilmiyah 1416 H/1994 M) cet.ke-1 Vol. 7 hlm. 275

56 Husein Husein Syahatah, al-Masharif al-Islamiyah Baina al-Fikr wa at-Tathbiq,Cairo : Dar al-nasr Lil jami'at 2009, hlm. 38

57 Prof. Dr. Ali Salus :Mausu'ah al-qodhoya al-Fiqhiyah al-Mu'asiroh wa Al-Iqtishod Al Islami, (Cairo : Dar al-Qur'an 2002 M) h.132.

58 Abu Abdullah Muhammad bin Yusuf Al-Abadri, Op.cit., hlm. 275. 
Pendapat ini juga sesuai dengan keputusan Majma' Fiqih Islam (OKI) di Abu Dhabi pada tanggal 1-5 Dzul Qo'dah $1415 \mathrm{H}$ yang menetapkan bahwa giro baik yang ada di bank syari'ah atau bank konvensional dalam pandangan fiqih termasuk akad simpan pinjam, karena pihak bank sebagai penerima titipan masuk kategori yad dhoman yang mengharuskan mengembalikan simpanan ketika diminta. ${ }^{59}$

\section{c. Prinsip Mudharabah dalam Deposito}

Secara etimologi mudharabahberasal dari kata dharbu satu makna dengan sairu, berarti memukul atau berjalan, artinya : berjalan dengan tujuan mencari rizki Allah Swt. ${ }^{60}$ Istilah Mudharabah (Masyarakat Irak) sepadan dengan Istilah Qiradh (Masyarakat Hijaz).

Menurut terminologi adalahMenyerahkan harta kepada pihak lain untuk dikelola dengan mendapat keuntungan bersama. ${ }^{61}$ Secara teknis, mudharabah adalah sebuah akad kerja sama antarpihak, yaitu pihak pertama (shahibul mal) menyediakan seluruh (100\%) modal; sedangkan pihak lainnya menjadi pengelola. ${ }^{62}$

Menurut UU No. 21 Tahun 2008 tentang Perbankan Syari'ah, mudharabah akad kerja sama suatu usaha antara pihak pertama (malik/shahibul mal, atau bank syari'ah) yang menyediakan seluruh modal dan pihak kedua ('amil/mudharib, atau nasabah) yang bertindak selaku pengelola dana dengan membagi keuntungan usaha sesuai dengan dengan kesepakatan yang dituangkan dalam akad, sedangkan kerugian ditanggung sepenuhnya oleh Bank Syariah kecuali jika pihak kedua melakukan kesalahan yang disengaja, lalai atau menyalahi perjanjian. ${ }^{63}$

Akad mudharabah adalah boleh, dasar hukum yang membolehkan akad mudharabah di anataranya adalah :

1) Firman Allah QS. Al-Nisa' (4) : 29 : Hai orang yang beriman! Janganlah kalian saling memakan (mengambil) harta sesamamu dengan jalan yang batil, kecuali dengan jalan perniagaan yang berlaku di antaramu......".

2) Firman Allah QS. Al-Maidah (5) :1: "Hai orang yang beriman, Penuhilah akadakad itu....".

3) Firman Allah QS. Al-baqarah (2) : ...Maka, jika sebagian kamu mempercayai sebagian yang lain, hendaklah yang dipercaya itu menunaikan amanatnya dan hendaklah ia bertakwa kepada Allah Tuhannya...".

4) Hadits Nabi riwayat Thabrani : "Abbas bin Abdul Muthallib jika menyerahkan harta sebagai mudharabah, ia mensyaratkan kepada mudharibnya agar tidak mengarungi lautan dan tidak menuruni lembah, serta tidak membeli hewan ternak.

Filosofi Mudharabah, yaitu manusia diciptakan oleh Allah SWT dengan berbagai kelebihan dan kekurangan. Ada orang yang mempunyai kelebihan harta, ada orang yang kekurangan harta, ada orang yang punya keahlian, tetapi tidak memiliki modal untuk melaksanakan suatu pekerjaan, ada orang yang punya modal tetapi tidak tidak punya waktu untuk mengurus sebagian hartanya. Untuk terjadinya keseimbangan, yang berpunya perlu membantu orang yang kurang dengan cara yang adil, sebab itu Islam menawarkan

59 Keputusan Majma’ Fiqih tentang Fiqih Muamalat; Oleh Prof.Dr. Yusuf Qordhowi, (Penerbit Ittihad Ta’wuni) Cet. 1, 1418 H-1997 M. h. 46-47

60 Ibnu Manzdur, Op.cit., h. 478

61 Syarbini, Mughni al-Muhtaj, Beirut: Dar al-Fikr 1419/1998., Cet. I, Vol. 2 h. 304

62 Muhammad Syafi'i Antonio, Bank Syariah wacana Ulama dan Cendekiawan, Jakarta: Tazkia Institute,. 1999, h. 171.

63 Penjelasan Pasal 19 huruf c UU Nomor 21 Tahun 2008 tentang Perbankan Syari’ah. 
berbagai solusi agar tidak terdapat kesenjangan di tengah masyarakat, maka mudharabah merupakan bagian dari pada cara yang ditawarkan Islam. ${ }^{64}$

Sedangkan deposito merupakan salah satu tempat bagi nasabah untuk melakukan investasi dalam bentuk surat-surat berharga.Pemilik deposito disebut deposan. ${ }^{65}$ Atau juga bisa dipahami sebagai simpanan untuk jangka waktu tertentu yang dapat diambil setelah jatuh tempo. Menggunakan bilyet sebagai tanda bukti simpanan dan diberikan imbalan berupa bunga/bagi hasil yang dibayarkan tiap akhir bulan. ${ }^{66}$

Secara umum penerapan akad mudharabah dalam produk deposito baik dalam jangka 1 bulan, 3 bulan, 6 bulan ataupun 12 bulan memenuhi standar prinsip-prinsip syariah. Tetapi ada beberapa prinsip syariah yang harus diperhatikan oleh setiap bank syariah terkait hal-hal teknis yang bisa membatalkan ke absahan akadmudharabah ;

1) Tidak adanya Ketentuan nisbah keuntungan Bagi Bank dan Nasabah

Salah satu prinsip penting yang menentukan keabsahan akad mudharabah adanya ketentuan keuntungan bagi hasil bagi pemilik modal ataupun pengelola dalam bentuk prosentase. Dari awal kedua pihak telah sepakat terkait jumlah prosentase keuntungan, kedua pihak harus mengetahui jumlah prosentase, atau jika lewat penawaran dari pihak bank pihak nasabah sebagai pemilik modal harus menerima yang dibuktikan dalam kontrak kerja.

Dalam prakteknya, ada bank syariah yang sejak awal tidak menjelaskan ketentuan keuntungan bagi hasilnya, sehingga nasabah tidak mengetahui prosentasi keuntungan yang didapatkan. Bahkan nasabah tidak memahami kontraknya, akad yang digunakan, nasabah hanya menandatangani kontraknya saja tanpa memahami isi kontraknya. Ketentuan ini sangat penting untuk menghindari konflik atau aduan dari nasabah terkait dengan keuntungan yang diperoleh.

Dan yang sangat disayangkan, sengaja atau adanya ketidakpahaman pegawai bank syari'ah justru menjelaskan suku bunga deposito yang diperoleh nasabah dalam akad mudharabah. Padahal ketentuan bunga adalah bagian dari riba yang dihindari dalam praktek bank syariah. Karena dalam akad mudharabah prinsip digunakan nasabah mendapatkan keuntungan ketika pengelola modal (bank) mendapatkan keuntungan dalam usahanya, sebaliknya jika merugi pihak nasabah menanggung kerugiaanya. Karena dengan alasan untuk menarik nasabah pihak bank memberikan jaminan keuntungan dalam akadnya.

2) Mengambil modal sebelum waktunya

Dalam akad Mudharabah prinsip yang digunakan adalah al-Ghunmu Bi al Ghurmi(keuntungan dan kerugian ditanggung bersama). Ketika proyek mendapatkan keuntungan, Permasalahnya adalah ada bank syariah yang membolehkan penarikan sebelum selesainya ketentuan proyek yang ada, belum terlihat hasil usaha yang dilakukan untung atau rugi.

Nasabah yang mengambil modal pada saat untung akan merugikan bank, sebaliknya nasabah yang mengambi modalnya pada saat rugi akan merugikan pihak nasabah. Hal tersebut menyalahi kaidah mudharabah karena belum selesainya akad yang disepakati.

\section{Kesimpulan}

Pertumbuhan keuangan syariah sangat berkaitan dengan erat dengan kepatuhannya terhadap prinsip syariah.Karena keuangan syariah dibangun oleh prinsip-prinsip syariah, maka harus berjalan dengan beriringan, ibarat dua keping mata uang yang tidak dapat dipisahkan.

64 Prof. Dr. H. Zainudin Ali, M.A., Op.cit., hlm.26

65 Kasmir, SE., MM., Dasar-Dasar Perbankan, Jakarta: RajaGrafindo Persada, 2005, h. 93.

66 Otoritas Jasa Keuangan, Produk Jasa Perbankan Syari'ah, h.144 
Apalagi keuangan syariahbertujuan menghasilkan output tidak hanya keuntungan materi, tetapi juga keuntungan spiritual yaitu keberkahan.

Semangat dalam mengembangkan produk dan memaksimalkan keuntungan di lembaga keuangan syariah adalah usaha yang harus ditingkatkan, bahkan diperlukan terobosan baru dalam mengembangkan produk-produk sehingga semakin memberikan keuntungan yang maksimal dan pilihan beragam bagi nasabah, tetapi semangat tersebut juga harus dibarengi dengan kesadaran tinggi keselarasan produk dengan prinsip syariah, sehingga lembaga keuangan syariah semakin maju secara materi dan spirit dan menjadi lembaga keuangan alternatif baik skala nasional maupun internasional.

Penguatan prinsip syariah tidak hanya dilakukan sebelum membuat kebijakan terkait keuangan syariah, tetapi saat proses keuangan syariah berjalan, dengan mengawasi proses produk yang ditawarkan bank syariah. Sehingga Keuangan syariah berjalan seiring dengan prinsip-prinsip syariah.

\section{Daftar Pustaka}

Al-Abadri, Abu Abdullah Muhammad bin Yusuf, 1994, Al-taj wa Al-Iklil Li Mukhtasor Kholil, Beirut: Dar al-Kutub al-Ilmiyah

Abu Habib, Sa'di, 1982, Qamus al-Fiqhi Lughatan wa Istilahan, Damaskus: Dar al-Fikri

Ali Shobuni, Muhammad, Tafsir Ayat Ahkam, Beirut : Dar al Kutub Ilmiyah

Amin Dhorir, Shiddiq Muhammad, 1993, al-Ghoror fil al-Uqud, Jedah : Bank Islami Li Tanmiyah

A. Karim, Adiwarman, 2008, Bank Islam Analisis Fiqih dan Keuangan, Jakarta: Grafindo Persada

Al-Sya'rowi , 'Aid Fadl, Al-Masyarif Al-Islamiyah Dirosah Ilmiyah Fiqhiyah lil Mumarosat Al-Amaliyah, Damaskus : Dar al-basyair al-Islamiyah

Asy-Syafi'i, Muhammad bin Idris, 1393 H, al-Um, Beirut : Dar al-Ma'rifat

Antonio, Muhammad Syafi'i, 1999, Bank Syariah wacana Ulama dan Cendekiawan, Jakarta: Tazkia Institute

Anshori, Abdul Ghofur, 2008, Aspek Hukum Reksa Dana Syariah di Indonesia, Bandung: Refika Adiama, 2008

ArifinZainul, 2009, Dasar-Dasar Manajemen Bank Syariah, Jakarta: Azkia Publisher

Jurjani, Ali, 1405 H., Al-Ta'rifat, Beirut: Dar al-Kitab al-Arobi

Kasmir, SE., MM., Dasar-Dasar Perbankan,(Jakarta: RajaGrafindo Persada, 2005)

Otoritas Jasa Keuangan, Modul Training of Trainers Keuangan Syariah (Roadmap Perbankan Syariah Indonesia 2015-2019

Salus, Ali, 2002, Mausu'ah al-qodhoya al-Fiqhiyah al-Mu'asiroh wa Al-Iqtishod Al Islami, Kairo: Dar al-Qur'an

Sjahdeni, Sutan Remy, 2014, Perbankan Syariah : Produk-Produk dan Aspek -Aspek Hukumnya, Jakarta: Kencana

Sarkhasi, Imam, al-Mabsuth, Beirut: Dar al-Ma'rifat

Sulami, Nasr Muhammad, 2008, Dhowabith Syar'iyah Lil-Istitsmar Iskandariyah: Dar alIman, 2008 
Syahatah Husein Husein, 2009, al-Masharif al-Islamiyah Baina al-Fikr wa at-Tathbiq, Kairo: Dar al-nasr Lil jami'at

Syarbini, Imam, Mughni al-muhtaj, Beirut: Dar al-Fikr

Taimiyah, Ibnu, Kutub wa Rasa'ilwa Fatawa Syekhul Islam IbnuTaimiyah, Kairo: IbnuTaimiyah

Qudamah Ibnu, al-Mughni, Kairo: Dar al-Kitab al-Arobi

Qardhawi Yusuf, 2000, Fawaidh al-Bunuk Hiya Riba, Jakarta: Usamah Press.

Qardhawi,Yusuf, Qararat Majma’ Fiqih Fi Fiqh al-Muamalat, Kairo: Ittihad Ta’wuni 